Annals of Tropical Research 30(1):93-112(2008)

@VSU, Leyte, Philippines

\title{
Appropriation of the information and communication technologies by farmers and extension workers in Borongan, Eastern Samar
}

\author{
Ulderico B. Alviola and Editha G. Cagasan \\ Department of Development Communication, Visayas State University, Visca, \\ Baybay City, Leyte 6521-A, Philippines
}

\begin{abstract}
This study aimed to describe how the information and communications technologies (ICTs) are being appropriated or adapted by farmers and extension workers to fit their day-to-day activities and to find out the consequences of using ICTs from the point of view of farmers and extension workers.

This study followed a qualitative case study design. Informants were identified using the snowball sampling technique. A total of 23 informants were interviewed, 13 of which were farmers and 10 were extension workers. Data were gathered using in-depth and unstructured interviews.

The grounded theory analysis was used to generate a model that describes how ICTs are appropriated by farmers and extension workers in Borongan, Eastern Samar. As shown by the model, the primary intentions for using ICTs were not agriculture-related. But because of certain facilitating factors, ICT use was later modified to fit the needs and lifestyle of farmers and extension workers. Their use of ICTs for agricultural purposes led to the following consequences: 1) savings in money and time; 2) fast access to information and instant communication; 3) convenience; 4) increased knowledge; 5) easier and faster accomplishment of job; 6) improved livelihood; 7) lessening of worries, dismay and embarassment; 8 ) increased demand for information and technical assistance from clients and 8) people's increased interest to learn.
\end{abstract}

Keywords: farmers' and extension workers ICT use, benefits of ICT, effect of ICT, Samar

Correspondence: U. B. Alviola. Department of Development Communication, Visayas State University (VSU), Baybay City, Leyte, 6521-A, Philippines. E-mail: ub.alviola@gmail.com. Tel: (053) 335-2650

DOI: $10.32945 /$ atr3017.2008 


\section{INTRODUCTION}

Considering its value in poverty alleviation (Alampay et al., 2003), information has proven itself to be an asset for development. Being so valuable, the nation's economies are now rolled into a dichotomy of classes - the information rich and the information poor. This dichotomy of classes is incessantly aggravated by a global gap shared among rich and poor countries and between wealthy and underprivileged individuals. This gap is termed as the digital divide (De Munster, 2004).

The digital divide is defined as the deficiency or the impossibility in technological access or ownership, whether in terms of hardware, software or connection (De Munster, 2004) and the difference in opportunities available to people who have access to modern information technologies and those who do not (Encyclopedia Microsoft Encarta, 2006). A gap which tends to deepen is produced between those individuals who have access to new information and communication tools such as TV sets or the Internet, and those who are too poor to get them.

In an attempt to bridge the digital divide and erase the fear of exacerbating the already existing economic gap between technological "have's" and "have not's", various information and communications technology for development projects were launched. These projects were aimed at reaching the informationpoor regions of the world. ICT tools (referring to new media and gadgets like computers and cellular phones, among others) were integrated into the fields like agriculture, education, health, social justice and commerce, among others to make them usable especially for the people living in developing countries (ICT for Development, 2003).

Examples of international projects harnessing the potentials of ICTs include the Swiss Agency for Development and Cooperation program and the Open Source Simple Computer for Agriculture in Rural Areas project. Both provide information that help farmers improve crop productivity and realize better crop price (ICT for Development, 2003; OSCAR Project, 2006).

In the Philippines, ICT is now being used by the government as a strategy to advance agricultural extension and communication programs. The potentials of technologies in information dissemination are being utilized to bring relevant information to every farmer. One example of a program which tries to use ICTs for development is the Techno Gabay (Technology Guide) Program 
(TGP). As one of the banner programs of the Philippine Council for Agriculture, Forestry and Natural Resources Research and Development (PCARRD), the TGP is designed to bring science-based information and technology services to the end users in agriculture, forestry and natural resources sectors. In Eastern Visayas, it is implemented through the Visayas Consortium for Agriculture and Resources Program, which is based at the Visayas State University (VSU) in Baybay City, Leyte.

ICT is one of the four component modalities of TGP. This project component facilitates storage, retrieval and exchange of information through computers and cellular phones to provide immediate response to current problems and frequently asked questions of farmers. It provides opportunities for capability enhancement through ICT trainings and Internet link offering unlimited chance to participate in e-commerce through quick information access (PCARRD, 2006).

Although current literature is replete with information on the potential benefits of ICTs, Michiels and Crowder (2002) argued that there is still lack of empirical evidence or analyses of actual experiences of applying ICTs locally and their impact upon poor people's economic and social livelihood. Accordingly, some community-driven, locally appropriated ICT initiatives and projects do exist. The problem, however, is that only very few projects pay attention to monitoring and evaluation of ICT outcomes, especially about the local impacts of technologies. Thus, guidelines for effective ICT deployment and appropriation at the local level are missing.

This study sought to find out how ICTs, particularly computers and cellular phones, are locally appropriated. FAO defined local appropriation as communities and groups selecting and adopting communication tools according to the different information and communication needs identified by them, and then adapting the technology so that it becomes rooted in their own social, economic, and cultural processes (Michiels and Crowder, 2002).

\section{METHODOLOGY}

This study was conducted in Borongan, Eastern Samar (Figure 1). The choice of this site was based on the following:

1. Borongan is one of the four TGP sites that were first provided with computers and cellular phones, among others. 


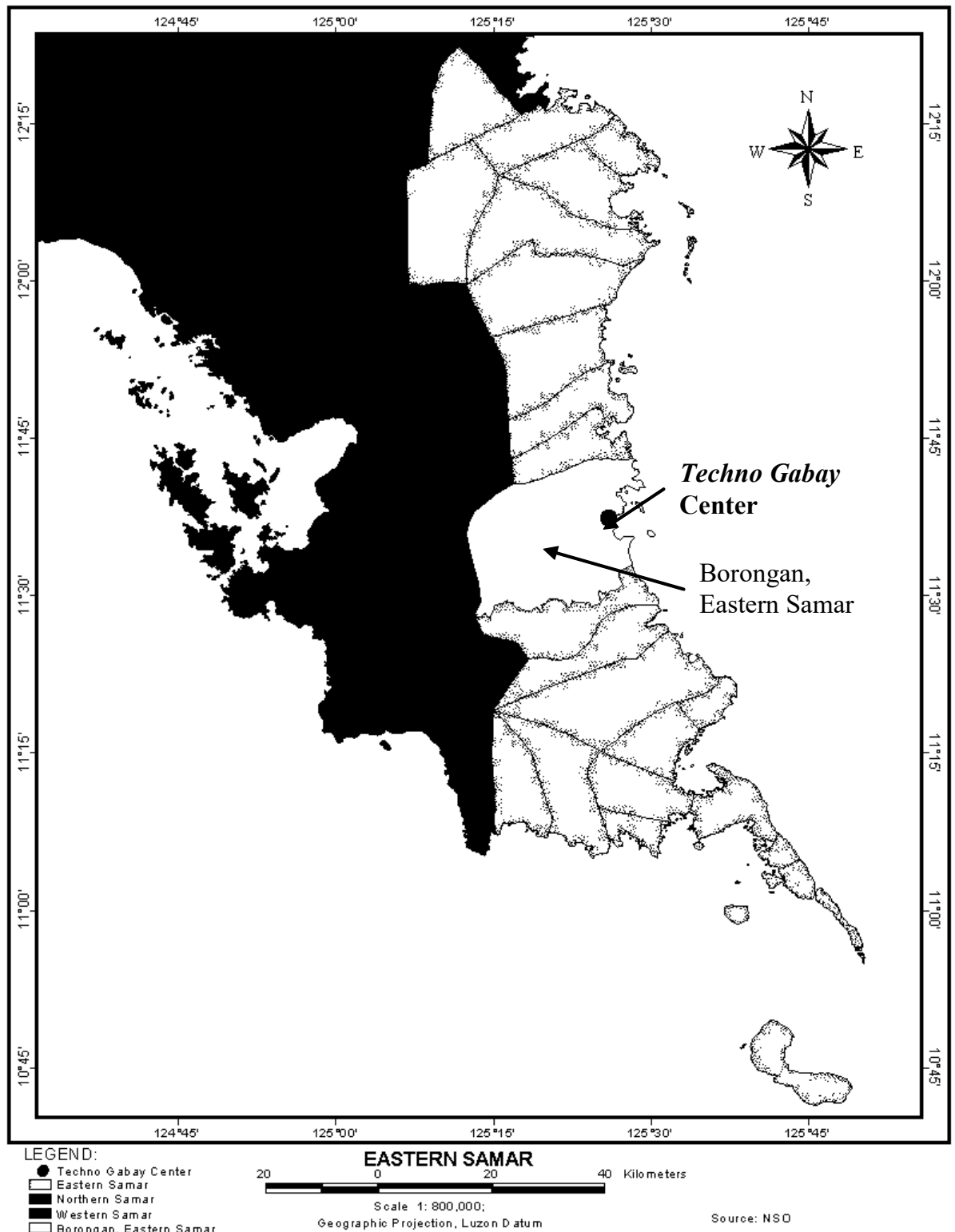

Figure 1. Map of Borongan, Eastern Samar showing the location of the Techno Gabay Center 
2. Agricultural extension workers reported positive benefits of the ICT interventions of the TGP. Thus, Borongan, Eastern Samar presents a unique and more interesting case of ICT application compared to other TGP sites.

To gain entry into the research site, the researchers coordinated with the Visayas Consortium for Agriculture and Resources Program (ViCARP), the agency in charge of the implementation of the TGP within the Eastern Visayas region. With the help of ViCARP, the researcher tied-up with the Office of the Provincial Agriculture Services (OPAS) of Borongan, Eastern Samar to gain entry to the research community. Letters were sent to the regional TGP coordinator, ViCARP director and the provincial agriculturist of Borongan, Eastern Samar to ask permission for the conduct of the study. Field activities proceeded only after gaining from the above offices. Also, a human subjects consent to participate form was distributed to the respondents of this research before data collection.

This study employed the qualitative case study approach. A qualitative case study is an exploration of a bounded system or a case (or multiple cases) over time through detailed, in-depth data collection involving multiple sources of information rich in context. This system is bounded by time and place, either a program, an event, an activity, or individuals. This particular study is an example of a within-site study, which focuses on a single program only. Multiple sources of information include observations, interviews, audio-visual materials, documents and reports (Creswell, 1998).

Snowball sampling technique was used to identify the informants. Patton (1990) noted that relatively small samples, even single cases selected purposively are acceptable. Sampling in qualitative inquiry is driven by the desire to illuminate the questions under study and to increase the scope or range of data exposed to uncover multiple realities. Unlike quantitative sampling where samples should be representative of some larger population to which one hopes to generalize the research findings, qualitative sampling concerns itself with information-richness (Lofland and Lofland, 1995).

Data were collected using in-depth and unstructured interviews. It consisted of a 14-hour audio recording with an average recording time of 40 minutes per informant. Recorded interviews were transcribed in verbatim to 
facilitate analysis.

To generate a model that would help describe the process of appropriation and the consequences resulting from farmers' and extension workers' adoption of ICTs, the grounded theory analysis (Figure 2), as advanced by Straus and Corbin (1990), was used.

\section{RESULTS AND DISCUSSION}

\section{Respondents}

A total of 23 informants were interviewed, 13 of them were farmers and 10 were extension workers.

Based on the NEDA's age classification, majority $(61.5 \%)$ of the farmerrespondents belonged to the senior citizen category while $38.5 \%$ were old. As to the extension workers, most $(60 \%)$ were old while informants belonging to the senior citizen and middle age category equaled to $20 \%$.

Most (53.8\%) of the farmer-informants were male while a little less than half $(46.2 \%)$ were female. As to extension workers, majority $(60 \%)$ were males while two-fifths $(40 \%)$ were females.

\section{Process of appropriation}

Analysis of the data using the grounded theory approach generated a model that shows how ICTs are appropriated by farmers and extension workers for agricultural purposes in Borongan, Eastern Samar (Figure 3). Based on the model, ICTs were not originally intended for use in agriculturerelated concerns. However, some factors led to ICT's use for agricultural purposes. Such kind of ICT utilization, as defined by several purposes and strategies, led to positive consequences.

Original purpose of using ICTs. Conversations with farmers and extension workers in the area revealed that their original intention to use ICT tools were not agriculture-related. For instance, respondent no. 7 said that she bought her first cell phone to keep track of her children working in Manila and to communicate with her daughter who already settled abroad. She was convinced 


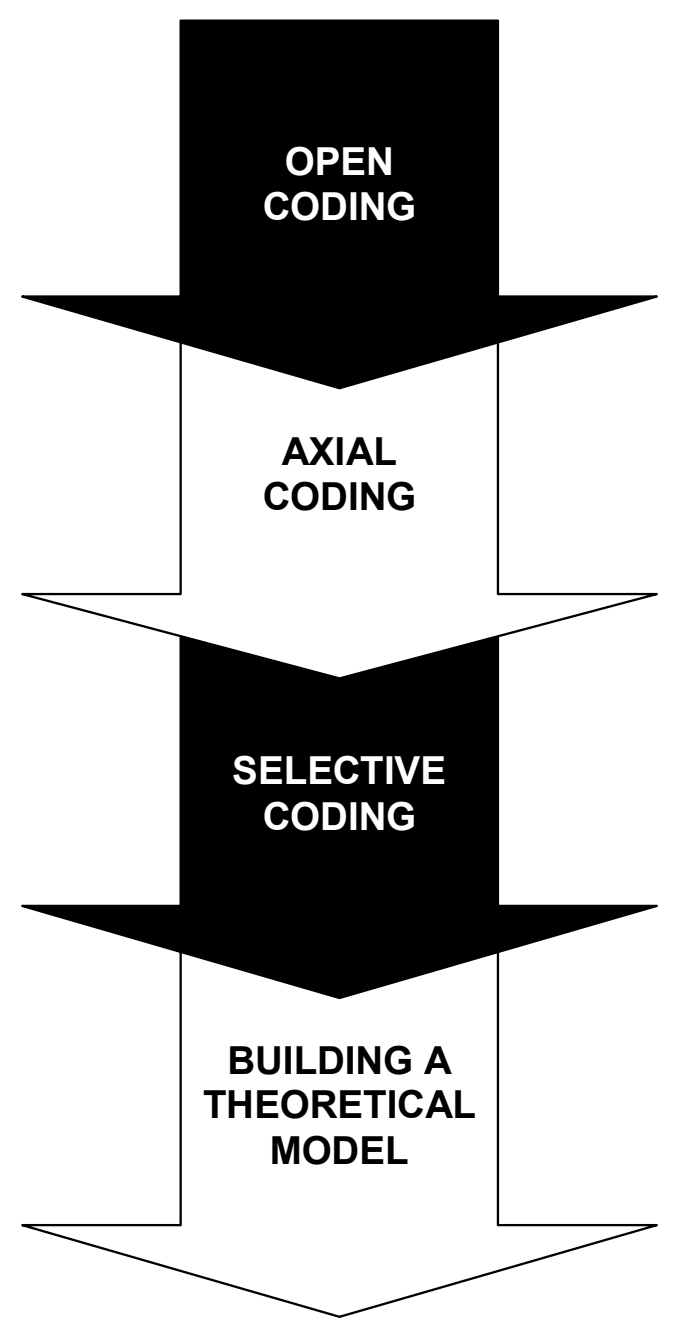

Figure 2. Steps in grounded theory analysis applied in this study (from Strauss \& Corbin, 1990). 





by her daughter to buy her own cell phone so that they will have contact with each other.

Respondent no. 6's case is somehow similar to that of respondent no. 7. He was forced to learn how to use the internet to chat with his wife who, at the time of the study, was working abroad. He revealed that he could save more with internet compared to using cellular phones and telephones. His purposes for adopting ICTs were, therefore, twofold: he wanted to keep his connection with his wife, and second, he wanted to save in terms of finances.

Respondent no. 21 also shared the same sentiments with the previously mentioned informant. Both of them used ICTs for personal and economic reasons. While the former intends to avail of the cheapest form of communication, the latter's reason was concentrated on the expenses his children incurred in renting for internet use in computer centers and cafes. He was getting bothered about their increasing expenses knowing that his children regularly go to internet shops to comply with their school requirements. Considering this, he was later convinced to purchase his own computer and put up his own internet connection at home. He was convinced that they could save more now since they only pay PhP995.00 (USD19.90) a month for both internet subscription and land line connection, unlike before that a hundred pesos was not enough for his children in a day because his children were really avid internet users.

Respondent no. 22, on the other hand, learned how to use ICTs back in his senior year when they were obliged to submit an encoded manuscript as final requirement for college graduation.

Respondent no. 16 presented a different case. Her primary reason for using the cell phone was because of fad and the fact that she wanted to have personal contact with her relatives and friends.

Facilitating factors. Results revealed facilitating factors believed by farmers that led them to use of ICTs for agriculture-related purposes. These included availability of ICT facilities, availability of ICT-literate extension workers and children, information needs, availability of mobile network signal and availability of load.

In the case of extension workers, seven facilitating factors encouraged them to use ICTs. These include availability of ICT facilities, opportunity for 
ICT use, attendance to ICT trainings and seminars, information needs, availability of mobile network signal, availability of load and internet connection.

As observed by the researcher, and as revealed by the informants, computer facilities are already available in Borongan before the TG Center's ICT facilities were installed. At the time of the study, 13 registered internet cafes were operating in Borongan with two cellular companies offering mobile network services. Although the computer facilities were recently made available for agricultural use, its potentials have not been maximized because according to the informants, the computers provided by TGP are not yet wired or internetconnected.

Borongan had a number of ICT literates who can serve as instruments in guiding and teaching non-literates to learn ICT skills. The records of TG showed that a few trainings and seminars were already conducted teaching farmers and extension workers how to operate ICT tools.

The case of using cellular phones is different from that of using computers. Cellular phone users have grown in Borongan and in other places due to increasing accessibility of mobile phones. During the conduct of the study, mobile phone service was not only limited to the town proper but it also reaches even the remotest communities of Borongan.

The case of respondent no. 21 exemplifies a unique facilitating factor in ICT use for agricultural purposes. The need for information pushed him to apply ICT in his work as an extension worker; a farmer asked about how to cure a particular disease in rice, which he did not quite know. Because he was not well versed in the concern raised by his farmer-client, he tried using the internet aided by his son who was already a computer literate. He used this opportunity to search for possible solutions to the problem raised by the farmer and was able to access solutions to the issue. From one of the seminars he attended at the Capitol, he learned that computer could be a powerful research tool. Since then, he started to put a space for ICTs in his work as an extension worker. He realized the value that can be offered by ICTs in his life.

Use of ICTs for agricultural purposes. ICT tools were not intended for agricultural purposes at first. However, with facilitating factors for ICT adoption and learning its uses, application in farming and extension activities was put in place. 
Two dimensions were found to define ICTs' application for agricultural purposes. These included the strategies of application and the modified intention or purpose for using the ICT tools.

In terms of using ICT application, four strategies emerged. These included integrating modern ICT tools such as computers and cellular phones with traditional ICTs like radio, assistance from trained TG personnel, tapping the assistance of ICT-literate children at home, and noting down newly learned information and technologies from the internet.

The case of Borongan is a very good example of integrating new ICTs with radio. Through radio station DYES, a government-supported media outfit operating under the supervision of the Philippine Broadcasting Service, disseminating agricultural information and technologies to farmers becomes easy for extension workers. With radio, local farmers are kept informed of the new farming technologies that increase their produce. OPAS launched several radio programs pertaining to agriculture so as to improve the extension services of the office. One of these is the weekly morning program entitled, "Kabukiran", anchored by the Information Service Specialist (ISS) of TG-Borongan.

As part of the ICT support of the TGP of ViCARP, the ISS of TGBorongan was given a cellular phone with a monthly load budget of $\mathrm{PhP} 500$ (USD10.00). When the project span ends, the recipient will be obliged to pay for all his monthly load expenses. Since the anchorman is a volunteer farmcaster at the radio station DYES, he regularly advertises his contact number to ask for feedback from his radio listeners every morning. His mobile phone has served to hasten the flow of communication between farmers and extension workers. From the testimonies of the informants, especially the farmers, they use their cell phones to keep contact with the TG staff. They use it when they need help on problems pertaining to agriculture.

Tapping the assistance of the trained TG staff in operating ICT tools is another strategy employed in Borongan, Eastern Samar. Farmers were being guided by extension workers in computer basics to provide them access to technologies. According to respondent no. 11, accessing information and technologies via the computer is not a problem for him since the TG staff are always willing to lend their hands to all farmers who need their help in terms of accessing information from the computer. 
The children of farmers and extension workers also play an important part in ICT adoption. Parents take advantage of the ICT literacy of their children by asking their assistance in operating ICT tools. Informants revealed that their children taught them how to use and operate ICT tools especially mobile phones. However, respondent no. 20 revealed that her dependence to her children made her less confident in using ICTs. This led to her disinterest in learning the cell phone.

Since his initiation, respondent no. 21 has been researching new agricultural technologies via the internet by logging the information he got from the internet in his field notebook. This serves as quick reference when the need arises.

As mentioned earlier, informants did not intentionally use ICTs for agricultural purposes. It was only later that they realized that ICTs can aid in their daily farming and extension activities. The use of ICTs in work has been an adaptive strategy, emerging from more personal and non-agricultural uses.

The extension workers reported that they use computers to prepare documents and reports and in the (re)production of reading materials. They also used it to research and to access latest information and farm technologies. In particular, they applied ICTs in disease diagnosis, market matching, marketing of products and solving field-related problems and concerns. Here is a sample of how an extension worker used the internet for disease diagnosis.

Sometimes I get plant samples and I research via the internet. .. I search in the internet because I know that I can find pictures of rice there. I will then compare the leaf color of my plant samples with the pictures posted on the net and read on the label of the disease and its symptoms (Respondent no. 21, lines 272-276).

ICT also functions as tool for inquiry in the case of farmers asking about information to the TG staff via SMS (Short Message Service). As explained by respondent no. 18 , for instance,

... when we have a problem, we text this office and we inquire. For example in swine raising, when our pigs are sick, we ask them what medicines to use (Respondent no. 18, lines 228; 232-233). 
Both farmers and extension workers also used ICTs to get connected with their family members working abroad or in other places in the Philippines. Moreover, they use other helpful features of ICTs such as that of calendar and organizer in cellular phones.

Problems that hinder ICT use. Farmers and extension workers reported eight problems that hinder ICT utilization. One limiting factor is the cost of using ICTs. Respondent no. 20 is convinced of the importance of ICT and is willing to buy a personal computer but not able due to income restraints.

The other limiting factor is competition between parents and children in computer time, with children tending to dominate over their parents when it comes to ICTs. Respondent no. 21 complained that the reason why he cannot learn how to operate his cell phone is because his children always take his mobile phone away from him. He cannot control his children since he knows that they are more familiar with ICTs compared to him.

Unstable electrical supply in Borongan also constrained ICT use. Borongan experiences occasional brownouts and blackouts. Often in weekends, the entire province of Eastern Samar experience blackout from 7:00 in the morning until 5:00 in the afternoon. Eastern Samar has been experiencing this problem for 3 years now as testified by respondent no. 23 .

Respondent no. 7 said that old age is a setback to ICT adoption. The older a person becomes, the lesser will be her interest when it comes to new technologies.

Having no common time between farmers and extension workers for training also restrains ICT application. Respondent no. 11 said that it would be too hard to look for a common time between farmers and extension workers to conduct ICT trainings because farmers are too busy in the field and extension workers are busy doing their jobs.

Although it is true that ICT facilities are already made available in the Techno Gabay Center, ICT facilities in the communities, especially in the remote villages of Borongan, are either inadequate or non-existent. It takes more than availability to make ICTs functional. Respondent no. 7 said that most farmers are less exposed to this kind of facilities, thus they do not give much interest in knowing how to use and apply it in farming activities.

There were several cases of load stealing as experienced by respondent numbers 18 and 20 . These discouraged them from using cell phones. Their 
load balance got deducted because of mobile network promotions. They even could not explain how they were registered and subscribed to daily tones and logo promos. Thus, they occasionally change their SIM (Subscriber's Identification Module) cards.

While the TG staff claimed to have conducted ICT trainings, a lone farmer, respondent no. 12, said that he lacks training on using ICTs. However, he emphasized that if OPAS will be sponsoring such an ICT training activity, he will be more than willing to participate in that activity.

\section{Consequences of using ICTs}

The consequences of ICT use that surfaced from the interviews were positive. These include the following:

Savings in money and time. Below are statements that tell how the ICTs helped farmers and extension workers saved money and time:

(When you travel), PhP22.00 will go to fare plus snacks. Perhaps, in your PhP100.00, only a little amount will be left for you. Instead, if I will just call, cost will be less. (Respondent no. 2, lines 348-350).

That (cell phone) is important so that we will no longer travel. You see, the fare is expensive. If you just text, you can save (Respondent no. 7, lines 404-406).

... you will have to pay for your fare in order to visit the DA office. How much is that?... That's PhP48! When you just text them, it becomes cheaper (Respondent no. 20, lines 301-304).

... And you can save your time. Instead of going to the nearest telephone station, cell phone is better because you can contact and talk to anybody, anywhere provided that you have signal (Respondent no. 11, lines 450-453).

If you don't have cell phone, your time is wasted. Instead of going here (OPAS), I should have spent my time to work in the farm and do some weeding. (Respondent no. 2, lines 382-385).

The ICT tools helped the farmers and extension workers save money. Farmers do not have to travel far to access the information. According to the 
extension workers, farmers coming from interior communities had to spend for transport to obtain information from OPAS. They also have to regularly visit the field to maintain contact with farmer-clienteles requiring bigger travel budget.

Using ICTs also enabled farmers and extension workers to save time. Farmers consider time as valuable as money. This is why they feel dismayed when they visit OPAS without getting anything from there. To them, time wasted could have allocated to farming. Extension workers confirm that ICT helps in saving time. With cellular phones, they do not need to spend hours of travels and could then better serve farmer clients.

Fast information and communication. Informants said that theybenefited from the potentials of ICTs in terms of speed in information and communication. Respondent no. 7 said that "... Talking about anything you want to know... you can reach them. You can contact anybody you want. About information that you would like to know, you can get it quick through cell phone.

Convenience. The internet provided convenience to both farmers and extension workers as to information searching. According to respondent no. 23, "Whatever you want to look for, it's all in there especially when you are connected to the internet." Respondent no. 6 seconded by saying that, "..in the internet, you obtain a wide range of information."

Like the extension workers, a farmer also experienced how useful the internet is as a source of agricultural information. According to respondent no. 11, "...Everything that you need pertaining to agriculture, for as long as you know how to use it, you can get it from the internet."

Increased knowledge. The capacity of ICTs to provide updated information led to the increased knowledge of farmers and extension workers in Borongan. As explained by respondent no. 23, "Because of ICT, especially the computer and the internet, people are more intelligent now. People's knowledge have become wider."

Easier and faster accomplishment of jobs. This applied to extension workers. Because of the presence of ICT facilities, their job becomes easier now. A good example of this is the case of respondent 22. He expressed that computers helped them do their job better and easier, unlike before that they use manual typewriters that requires a long time to prepare documents and 
reports. He said:

"...this (ICT) is a technology intended to make our job easy because computers help a lot in doing our job. The burden of work has lessened because we are no longer experiencing difficulty in researching especially with the books that we need to read. Reporting and reproduction of documents have become easy and like what I said a while ago, researching also becomes easy. (Respondent no. 22, lines 198-200).

Another example is the case of respondent 21 . The ICTs, particularly the cellular phone, enabled him to quickly respond to farmers' requests.

Before when I'm at work, some farmers would ask me to buy medicines (for their sick animals). Only the next day that we can respond to their problems. But now that we have communication through cell phone, sometimes they will call me while I'm still in Borongan. Instantly, I am able to bring them what they need. So, we are able to answer the problem directly. Before, I had to go back to Borongan just to purchase the medicines they need. (Respondent no. 21, lines 487-494).

Improved livelihood. Farmers mainly testified to this. Through the use of ICTs, particularly cellular phones, they were able to contact buyers and market their farm products even in other places. Below are some of the farmers' testimonials:

... My cell phone number is written on the bottle label of my virgin coconut oil. Some of my customers ask me, Manang Lydia, do you still have virgin coconut oil? I tell them to drop by in my house through texting. In marketing, cell phone becomes an effective tool. Everytime they ask me if I still have stocks, I text them to drop by. That is, if I still have enough stocks. (Respondent no. 7, lines 367-374).

... as far as business is concerned, I am using the cell phone since I have clients asking me if I still have available rice seeds at home. (Respondent no. 11, lines 438-440).

...To sell my products, I just text the buyers. I have their contact 
numbers. Before, I just wait for buyers of my pigs or fish to come. When I had ample fish catch, I was forced to bargain it since I didn't have buyers. (Respondent no. 19, lines 263-264; lines 269-271).

Lesser worries, dismay and embarrassment. Informants also revealed that ICT lessens their worries as they can immediately contact people in case of problems. Respondent no. 20 said that when she needs rice seeds for her farm, she just contact the technicians in OPAS through her cell phone:

"When I need seeds, all I have to do is to contact Sir (Opeña) to inquire if there are still available seeds...And then, I get a reply immediately if there are stocks so I will immediately go to OPAS since I'm in need. I don't worry anymore... because I know that there are available stocks... and I know where to get it." (Respondent no. 20, lines 352358).

ICTs also prevent dismay on the part of farmer-clients, and embarrassment of extension workers. According to respondent numbers 21 and 23, farmers get dismayed when some of their queries were not answered and solved. The extension workers, on the other hand, got embarrassed when they could not respond to the clients' needs. The extension workers were able to attend to the needs of their clients because of the ICT facilities.

Increased demand for information and technical assistance. As a result of the better and expanded services offered by the extension workers through the use of their ICT facilities, more clients' problems are solved. Thus, more clients are served by the extension workers. Respondent no. 23 said that his farmer-clientele would send him text messages asking for his assistance and advice even beyond office hours.

Arouse people's interest to learn. Respondent no. 22 said that he feels excited and interested when he is surfing the internet. This is because, for him, the information posted in the internet are more attractive than those found in books. He said that books are boring compared to the internet. He found that the latter is more inviting in the presentation of facts and data.

Overall, the process of ICT appropriation by farmers and extension workers can be explained by Giddens' (1984) structuration theory. Giddens 
said that human agents discursively and recursively form the set of rules, practices, and routines, which over time and space constitutes their conception of structure. Human agents according to Gidden's theory, have the capacity to make a difference. Technologies like ICTs are regarded as intervention into the relationship between human agents and organizational structure. Technology also has its own set of rules that are posed to people. But because human agents have the capacity to make a difference, humans test these rules and come up with a new set of rules based on the social meanings people put into certain technologies. This is what happened in Borongan, Eastern Samar. Farmers and extension workers first tested the ICTs, and later modified its use to fit their day-to-day farming and extension activities.

\section{IMPLICATIONS AND RECOMMENDATIONS}

This study generally aimed to understand how ICTs are locally appropriated or adapted by farmers and extension workers in Borongan, Eastern Samar. Current literature indicates that there are only a few fieldbased research studies or projects aimed at identifying qualitatively shaped accounts of people about certain phenomena such as ICTs. This study is the first attempt in the Philippines to provide a theoretical model on how the process of ICT appropriation for agriculture happens. This theoretical model may be used as a guide for other development program implementers in designing ICT projects in the rural areas.

The case of Borongan depicts several instances where people experienced the positive results of technology adoption. One lesson gleaned from this case is that if technologies are situated into an appropriate context, these can help enable development in rural communities. Therefore, there is a need to situate ICT infrastructure projects based on the needs and lifestyle of the people in the community. This will avoid ICT infrastructure to fail as emphasized in various literatures on ambitious ICT projects launched by governments and other international agencies.

Findings of this study also show that the integration of new ICTs (computer and cellular phones) with traditional ICTs (e.g. radio) has been successfully used in Borongan. Cellular phones are used in facilitating two-way communication while computers are serving as information sources for farmcasters. These imply that converging new and traditional ICTs will be 
helpful and beneficial to facilitate ICT utilization of farmers and extension workers.

Although this study depicted positive consequences in ICT adoption, some factors were also found to restrict farmers and extension workers from using ICTs. One of which is the lack of ICT trainings. It is, therefore, recommended that trainings be conducted to encourage our farmers and extension workers to use ICTs for development purposes. Another limitation is the wrong notion that ICT is only for the younger people. There is a need to correct this misconception so as to encourage our farmers and extension workers to use ICTs.

Finally, this study showed that children have a vital and critical role in ICT adoption. This underscores the need for development planners to consider the role played by children in the use of ICTs. Workshop sessions may be organized to conscientisize children to support their parents' desire in improving productivity. Considering children's relatively high technology literacy, they may also be requested to provide their parents hands-on trainings on the actual operation of a certain technology.

\section{LITERATURECITED}

ALAMPAY E., R. HEEKS and P.P. SOLIVA. 2003. Bridging the information divide: A Philippine guidebook on ICTs. University of the Philippines Press, Quezon City, Philippines.

CRESWELL, J. 1998. Qualitative inquiry and research design. Sage Publications, Thousand Oaks, CA.

DE MUNSTER, I. 2004. The digital divide in Latin America: A case study. Proceedings of the World Library and Information Congress: 70th IFLA General Conference and Council. Buenos Aires, Argentina.

ENCYCLOPEDIA. Microsoft Encarta 2006 [CD-ROM]. Microsoft Corporation, 2005, Redmond, WA.

GIDDENS, A. 1984. The constitution of society: The theory of structuration. Retrieved January 2, 2007 from the http//:www.theory.org.uk/giddens2. htm.

ICT for Development. 2003. SDC project examples in ICT4D. Retrieved September 01, 2006 from http//:www.ictfordevelopment.wordpress.com/tag/agriculture. 
LOFLAND J. \& L. LOFLAND (1995). Analyzing social settings: A guide to qualitative observation and analysis. Wadsworth Publishing, NM.

MICHIELS, S.I. and V. L. CROWDER. 2002. Discovering the magic box: Local appropriation of Information and communications technologies (ICTs). FAO Press, Rome.

PATTON, M. (1990). Qualitative evaluation and research methods. Sage Publications, Thousand Oaks, CA.

PCARRD, 2006. Techno Gabay Program. Philippine Council for Agriculture, Forestry and Natural Resources Research and Development (PCARRD). Department of Science and Technology. PCARRD Information Bulletin No. 134A/2006.

STRAUSS, A. and J. CORBIN. 1990. Basics of Qualitative Research: Grounded Theory Procedures and Techniques. Sage Publications, Thousand Oaks, CA.

The OSCAR Project. 2006. An exercise in ICT, agriculture and society. Retrieved July 22, 2006 from http//:www.i4donline.net. 